\title{
Interactions between benthic macroinvertebrates and fishes in a low order stream in Campos de Cima da Serra, RS, Brazil
}

\author{
Winckler-Sosinski, LT. ${ }^{\mathrm{a} *}$, Silveira, TCL. ${ }^{\mathrm{b}}$, Schulz, $U H .{ }^{\mathrm{c}}$ and Schwarzbold, A. $^{\mathrm{d}}$ \\ ${ }^{a}$ Empresa Brasileira de Pesquisa Agropecuaria - EMBRAPA Clima Temperado, \\ BR 392, Km 78, CP 403, CEP 96001-970, Pelotas, RS, Brazil \\ 'Laboratório de Invertebrados Bentônicos I, Departamento de Zoologia, Instituto de Biociências, \\ Universidade Federal do Rio Grande do Sul - UFRGS, \\ Av. Bento Gonçalves, 9500, CEP 91501-970, Porto Alegre, RS, Brazil \\ 'Laboratório de Ecologia de Peixes, Universidade do Vale do Rio dos Sinos - UNISINOS, \\ Av. UNISINOS, 950, CEP 93022-000, São Leopoldo, RS, Brazil \\ ${ }^{d}$ Departamento de Ecologia, Laboratório de Limnologia, Instituto de Biociências, \\ Universidade Federal do Rio Grande do Sul - UFRGS, \\ Av. Bento Gonçalves, 9500, CEP 91540-000, Porto Alegre, RS, Brazil \\ *e-mail: lilianws@cpact.embrapa.br \\ Received August 1, 2006 - Accepted March 7, 2007 - Distributed November 30, 2008
}

(With 2 figures)

\begin{abstract}
Benthic macroinvertebrates constitute the link between organic matter input in streams and fishes. However, the possibility of influence of predators on the invertebrates is still a controversial issue. The possibility of alteration of the benthic community by the modification in predation in a stream in the South of Brazil was studied by means of an exclusion experiment under semi-natural conditions. The exclusion showed an increase in the abundance of Plecoptera in the river where the rainbow trout was introduced, the larvae of Trichoptera also increased in abundance in the units of fish exclusion. This difference does not confirm the pressure applied by the trout on the benthic macro fauna due to differences in ichthyofauna and in the habitat of both rivers. Nevertheless, it points to the need for the development of studies concerning the trophic relations and the possible effects of this introduction in the aquatic biota.
\end{abstract}

Keywords: benthic macroinvertebrates, low order streams, predation, exclusion experiment, exotic fish.

\section{Interações entre macroinvertebrados bentônicos e peixes em um rio de baixa ordem nos Campos de Cima da Serra, RS, Brasil}

\begin{abstract}
Resumo
Os macroinvertebrados bentônicos exercem a ligação entre a entrada de matéria orgânica nos rios e os peixes. Porém, a possibilidade de influência dos predadores sobre os invertebrados é uma questão ainda controversa. A possibilidade de alteração da comunidade bentônica, pela modificação na predação em um rio no sul do Brasil, foi estudada através de um experimento de exclusão em condições seminaturais. A exclusão resultou no aumento na abundância de Plecoptera no rio onde é feita a introdução de truta arco-íris; as larvas de Trichoptera também aumentaram em abundância nas unidades onde se efetuou a exclusão. Essa diferença não pode ser atribuída à presença das trutas, devido às diferenças na ictiofauna e de habitat dos dois rios. Entretanto mostra a necessidade de desenvolvimento de estudos acerca das relações tróficas e possíveis efeitos desta introdução sobre a biota aquática
\end{abstract}

Palavras-chave: macroinvertebrados bentônicos, riachos de baixa ordem, predação, experimento de exclusão, peixe exótico.

\section{Introduction}

Benthic macroinvertebrates have an essential role in the maintenance of river communities by the linkage established in the food chain between organic matter and fishes (Hauer and Resh, 1996). Aquatic biota is structured through this linkage according to the river continuum concept proposed by Vannote et al. (1980).

As species are not independent entities - taking into account that biotic and abiotic connections are es-

sential for the maintenance of integrity of the lotic systems - the quantification of predator impact on the abundance of prey has been studied by some authors (Thorp and Bergey, 1981; Flecker and Allan, 1984; Wilzbach et al., 1986; Rahel and Stein, 1988; Soluk and Collins, 1988; Lancaster, 1990; Cooper et al., 1990; Hanson et al., 1990; Flecker, 1992; Prejs and Prejs, 1992; Bechara et al., 1993; Lancaster and Robertson, 
1995, McIntosh and Townsend, 1996; Dahl, 1998; Billy and Usseglio-Polatera, 2002). Amongst the factors that influence the response of prey to predator are: a) predator feeding characteristics, being that not all the taxa are affected (Billy and Usseglio-Polatera, 2002); b) size of prey and substrate type, presenting a higher or lower degree of shelter sites (Bechara et al., 1993) and c) types of habitats, which may have a differentiated effect, taking into consideration that in habitats made up of riffles and rapids, colonization rates are higher than in pools, causing a lower response to predators (Cooper et al, 1990). Dahl (1998) considers the control of macroinvertebrate density in rivers and streams by fishes as a controversial issue, but the fish certainly exert influence on the behavior of the prey, sometimes to sub-lethal levels.

Thus, changes in the autochthonous fish assemblage may result in unexpected variations in the biota of rivers and streams. The practice of introduction of fishes has, therefore, still unknown effects. Brazil stands out among neo-tropical countries due to its higher number of introductions (Delariva and Augustin, 1999). Even though a great part of the studies concerning the effects of introduced fishes evaluates its consequences for native fishes (Flecker and Towsend, 1994), the negative impacts of invaders are not restricted to the fish assemblages (Gido and Brown, 1999). Flecker and Towsend (1994) point to the subtlety of the effect of invaders on the organization of the community, which may be of an indirect form and in cascade through multiple trophic levels, which results in underestimated effects of the introduction. McIntosh and Towsend (1996) reported this cascade effect in a stream of New Zealand under the effect of the introduction of the brown trout, in which there was an increase in the amount of chlorophyll- $a$ due to changes in the behavior of Ephemeroptera in view of the presence of the trout.

The aim of this work is to verify the consequences of predation by fish on the benthic macroinvertebrates community of low order streams in the south of Brazil by means of an exclusion experiment, and to identify differences between streams with presence and absence of the exotic rainbow trout species (Oncorhynchus mykiss (Walbaum, 1792)).

\section{Materials and Methods}

The study area is located in the municipality of São José dos Ausentes, in the northeast region of the State of Rio Grande do Sul, Brazil (Figure 1). Two streams belonging to the Silveira river watershed were surveyed in order to verify the effect of ichthyofauna on the benthic macrofauna. In the studied stretch, systematic introductions of rainbow trout have been carried out for sport fishing since the middle of the 90's. Near the site of the installation of the experiment, the margins of the stream present an activity of extensive cattle production, with occasional use of fire. The Marco stream, a tributary of the Silveira river, is a fourth order stream in the studied stretch, where no introductions were made, its margins are occupied for pasture areas with the same characteristics of the Silveira stream and a Pinus sp. plantation in the headwater.

The autochthonous ichthyofauna of the Silveira stream comprises the following species: Astyanax sp., Bryconamericus sp., Steindachnerina biornata (Braga and Azpelicueta, 1987), Australoheros facetus (Jenyns, 1842), Cnesterodon brevirostratus (Rosa and Costa, 1993), Rhamdia quelen (Quoy and Gaimard, 1824), Trichomycterus sp., Eurycheilichthys pantherinus (Reis and Schaefer, 1992) and Pareiorhaphis hystrix
Rio Grande do Sul

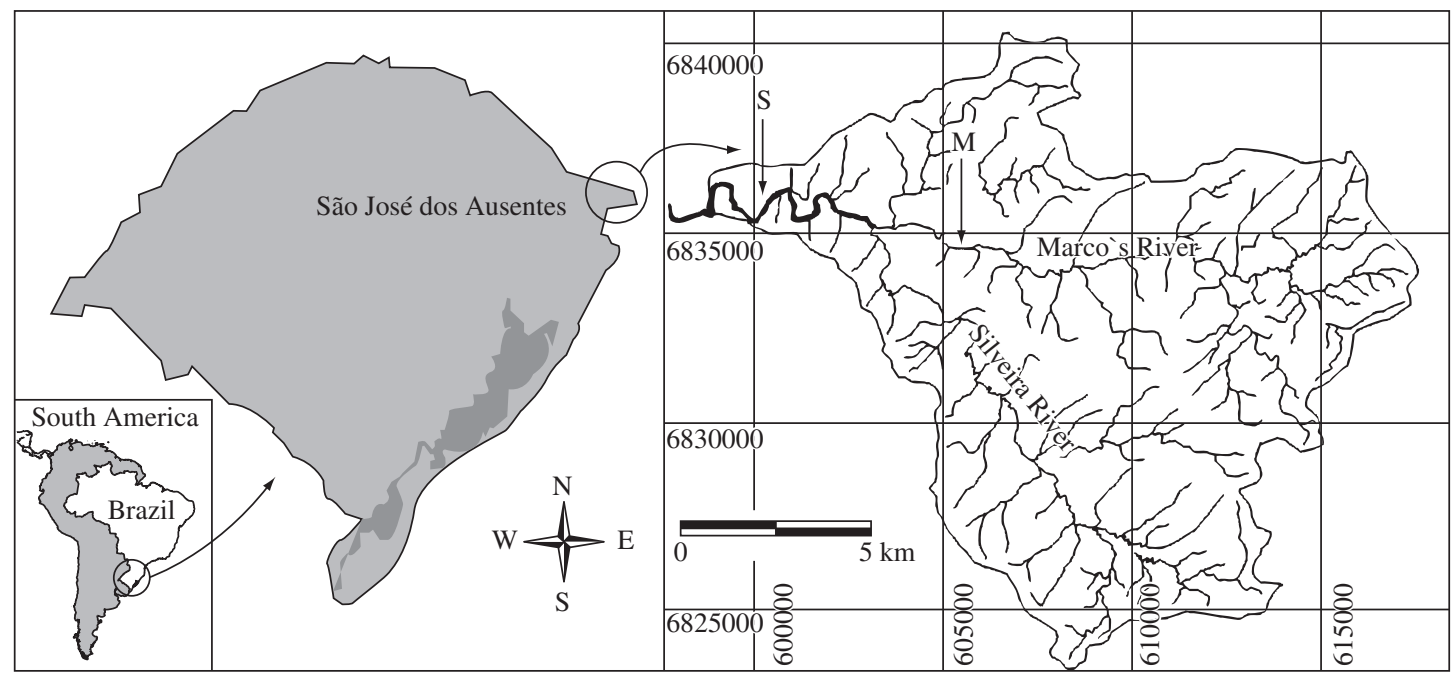

Figure 1. Sites of location of the fish exclusion experiment are indicated by gray arrows, being $S$ the site in Silveira stream and $\mathrm{M}$ the site in Marco stream. 
(Pereira and Reis, 2002), as well as the exotic species Oncorhynchus mykiss. According to Winckler-Sosinski (2004) the Marco stream presents the same autochthonous species of the Silveira stream plus the species A. brachypterygium (Bertaco and Malabarba, 2001) and Jenynsia eirmostigma (Ghedotti and Weitzman, 1995). In the Silveira stream, the experiment was located near to arboreal vegetation promoting a shaded setting, while in the Marco stream, the experiment was located near to grassland vegetation, without shade.

An exclusion experiment was performed in situ, and the homogeneity of substrate composition and water flow were observed. Thirty-two (32) experimental units were exposed, composed of plastic trays of $0.06 \mathrm{~m}^{2}$ in area, sixteen (16) units of which were disposed in each stream. Factors like exclusion and time of colonization were tested for each stream. Eight (8) exclusion units were exposed in each stream, being half of them tested for 36 days of colonization and the others for 72 days. The exclusion was performed by means of a tray enveloped in a plastic mesh of $1 \mathrm{~cm}$ in order to allow the colonization of different organisms but to prevent predation by fishes. Among the fishes found in the stream, the mesh excluded larger size classes of Astyanax sp., Bryconamericus sp., Steindachnerina biornata, Australoheros facetus, Rhamdia quelen, Eurycheilichthys pantherinus and Pareiorhaphis hystrix, as well as the exotic Oncorhynchus mykiss. In the Marco stream, besides the autochthonous species listed, samples of a bigger size of $A$. brachypterygium could also be excluded.

The experimental units with 36 days of colonization were re-exposed to colonization, being withdrawn concomitant to the experimental units with 72 days of colonization. The substrate fauna was removed by light scrubbing, enabling the permanence of periphyton, and restored to the tray at its original position on the streambed. The gravel was separated in two classes, as follows: big gravel with an average perimeter of $25 \mathrm{~cm}$ on its bigger side, and small gravel with average perimeter of $10 \mathrm{~cm}$ on its bigger side.

The abiotic variables evaluated were speed of water and depth of location, measured in front of each tray at the moment of installation and withdrawal. At the same time, the temperature of the water, $\mathrm{pH}$ and electric conductivity were measured for each stream studied. None of these variables was used for comparison since it was performed on different days and so might have presented large oscillations during this period, without produce alterations in the benthic macrofauna. At the moment of withdrawal, the samples were enveloped in a mesh of $250 \mu \mathrm{m}$ in order to prevent the loss of macrofauna due to drift. After removal, the tray, the exclusion mesh and the pebbles were gently scrubbed to remove fauna which was then preserved in alcohol $(70 \%)$ for further identification.

At the lab, the organisms were assessed and identified under an estereo-microscope up to the level of
Order, based on McCafferty (1981), Strixino and Strixino (1982), Merritt and Cummins (1996) and Férnandez and Dominguez (2001).

The congruence between the abiotic and biotic variable sets of both streams was tested by means of the application program SYNCSA (Pillar, 2004b), using as similarity measure the distance of the rope. The results of abundance were submitted to a test of randomization (Pillar and Orlóci, 1996) in order to verify the differences between the exclusion and period of colonization factors and also for the verification of the differences among the units of 36 days of colonization repeated in the time. The results of each stream were analyzed separately using the chord distance as a similarity measure. The orders were tested as to the abundance, separately, to verify the difference between the exclusion and period of colonization factors and also for the verification of the differences between the units of 36 days of colonization repeated in the time using Euclidean distance as similarity measure. The big and small gravel number variables, mean depth and mean temperature were submitted to the randomization test to verify their similarity, using as similarity measure Gower's index. The randomization tests were performed using the application program MULTIV (Pillar, 2004a).

\section{Results}

The amount of gravel of bigger and smaller size placed in each one of the units, as well as the speed of the water and its depth at the moment of installation and withdrawal of the experiment are described in Table 1. The abiotic variables are described in Table 2. The randomization test separated the streams through the abiotic variables $(\mathrm{P}<0.05)$, being that the variable more correlated with taxons was speed $(\mathrm{P}<0.05)$. The ordination showed that axle 1 had a great percentage of the explanation for the variation $(74.5 \%)$ as shown in Figure 2. In this figure it is possible to verify the separation of both streams, the Marco stream being negatively associated to axle 1. Both streams were separated basically as to the presence of Diptera, Ephemeroptera and Gastropoda. Silveira stream showed the highest values

Table 1. Characterization and quantity of gravel (big and small) inserted in the sampling units, mean depth and mean speed at the moment of the installation (day 1 ) and the withdrawal (36 and 72 days) in Marco and Silveira streams.

\begin{tabular}{lccc}
\hline & & \multicolumn{1}{c}{ Silveira } & \multicolumn{1}{c}{ Marco } \\
\hline Gravel number & Big & $27.2 \pm 2.8$ & $25.5 \pm 4.7$ \\
& Small & $12.5 \pm 1.2$ & $13.5 \pm 1.5$ \\
Depth $(\mathrm{cm})$ & 1 & $34.7 \pm 4.2$ & $35.3 \pm 6.1$ \\
& 36 & $28.0 \pm 2.3$ & $28.0 \pm 4.7$ \\
Water speed $(\mathrm{m} / \mathrm{s})$ & 1 & $0.19 \pm 0.05$ & $0.10 \pm 0.04$ \\
& 32 & $32.2 \pm 2.2$ & $33.6 \pm 6.9$ \\
& 72 & $0.20 \pm 0.05$ & $0.19 \pm 0.06$ \\
\hline
\end{tabular}


Table 2. Temperature in $\left({ }^{\circ} \mathrm{C}\right)$, electrical conductivity $\left(\mu \mathrm{S} . \mathrm{cm}^{-1}\right)$ and $\mathrm{pH}$ at the moment of installation and withdrawal of the experiment, in Silveira and Marco streams.

\begin{tabular}{lrrrr}
\hline & \multicolumn{2}{c}{$\begin{array}{c}\text { Marco } \\
\text { stream }\end{array}$} & \multicolumn{2}{c}{$\begin{array}{c}\text { Silveira } \\
\text { stream }\end{array}$} \\
\hline Day & 1.00 & 72.00 & 1.0 & 72.0 \\
Temperature $\left({ }^{\circ} \mathrm{C}\right)$ & 9.00 & 25.60 & 12.5 & 15.0 \\
Conductivity $\left(\mu \mathrm{S} . \mathrm{cm}^{-1}\right)$ & 23.20 & 25.60 & 19.9 & 19.1 \\
$\mathrm{pH}$ & 6.63 & 6.25 & 6.3 & 6.3 \\
Dissolved oxygen $\left(\mathrm{mg} . \mathrm{L}^{-1}\right)$ & 10.55 & - & 10.7 & - \\
\hline
\end{tabular}

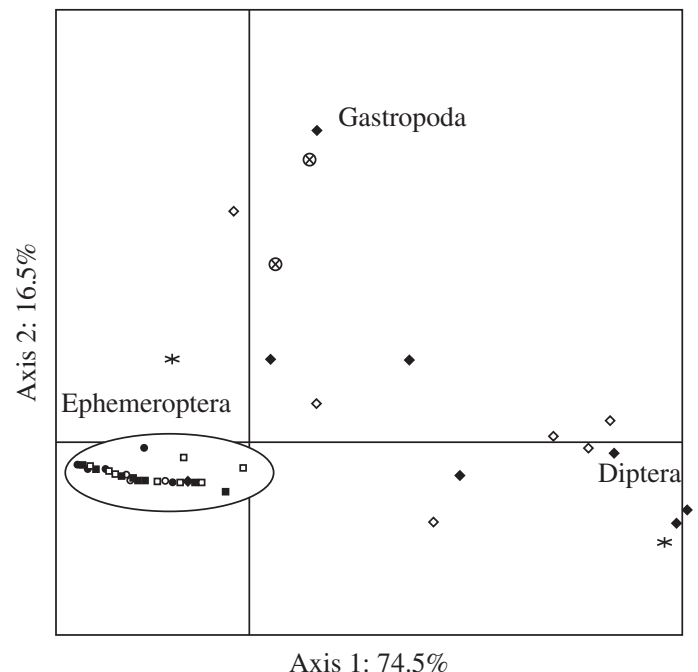

Figure 2. Biplot of the sampling units and species more correlated to the axes. Ephemeroptera with -0.98 with axis 1 , Diptera with 0.98 with axis 1 and Gastropoda 0.29 with axis 2. The symbols mean: $\bullet$ Silveira stream treatment of exclusion 36 days of colonization: $*=$ Silveira stream treatment of exclusion 72 days of colonization; $\diamond=$ Silveira stream open treatment 36 days of colonization; $\otimes=$ Silveira stream open treatment 72 days of colonization; $\mathbf{a}=$ Marco stream treatment of exclusion 36 days of colonization; - = Marco stream treatment of exclusion 72 days of colonization; $\square=$ Marco stream open treatment 36 days of colonization; $\mathrm{O}=$ Marco stream open treatment 72 days of colonization. All the circled sampling units belong to Marco stream.

for Diptera and Gastropoda, while higher amounts of Ephemeroptera were associated to Marco stream. Six sampling units were lost in the Silveira stream due to trampling of cattle that occasionally enter the stretch of the stream, and the difficulties in sample withdrawal due to water flow as well.

The organisms of benthic macrofauna found in the trays belong to many taxa such as: Ephemeroptera, Diptera, Coleoptera, Trichoptera, Hemiptera, Lepidoptera, Gastropoda, Plecoptera, Megaloptera (only in Marco stream), Aegla spp., Acarina, Oligochaeta, Odonata, Hirudinea, Bivalve and Collembola (only in Marco stream). The highest abundance was verified in decreasing order respectively for Diptera (49.3\%), Ephemeroptera (27.8\%), Gastropoda (12.0\%), Trichoptera $(4.8 \%)$, Coleoptera $(2.3 \%)$ and Plecoptera (2.0\%), for Silveira stream, while in Marco stream the highest abundance was of Ephemeroptera (76.3\%), Diptera (12.4\%), Coleoptera (4.8\%), Trichoptera (2.4\%), Plecoptera $(1.1 \%)$ and Lepidoptera (1.0\%), respectively (Table 3). Silveira stream showed higher amount of organisms $(\mathrm{P}<0.05)$ than Marco stream.

When all taxa in Silveira stream were analyzed, there was no difference neither between the opened units and the exclusion units, among the units of 36 days of colonization repeated over time, nor among the different periods of colonization $(\mathrm{P}>0.05)$. Marco stream presented differences $(\mathrm{P}<0.05)$ when the units of 36 days of colonization placed in the first period were compared to the ones placed in the second period.

Analyzing taxons separately in Silveira stream, Trichoptera and Plecoptera presented significant differences $(\mathrm{P}<0.05)$ between the opened units and those with exclusion of predators, having a higher abundance in the latter. Ephemeroptera and Lepidoptera showed significant differences when compared to the time of the samples withdrawal, being that the highest abundance of Ephemeroptera was observed when the units were removed in July, while Lepidoptera occurred only in July. Colonization did not present significant differences for any of the taxons.

In Marco stream, only Plecoptera presented significant increase on the exclusion treatment $(\mathrm{P}<0.05)$. The withdrawal time of the units presented a statistical significance $(\mathrm{P}<0.05)$ for Ephemeroptera and Lepidoptera, which reached highest abundance in the units removed in July. Colonization presented significant differences $(\mathrm{P}<0.05)$ for Trichoptera and Plecoptera, which reached higher abundance after 72 days of colonization.

\section{Discussion}

The use of artificial substrate may interfere in the dynamics of the predator-prey relationship (Flecker and Allan, 1984). For this reason, the natural substrate of the river was used for filling the sampling units. However, due to lack of local information regarding the time of colonization of aquatic macrophytes, present in great amount in the riverbeds of the region, mainly Podostemaceae, this substrate had only its fauna removed.

The time of colonization of the artificial substrate is still discussed, since it will vary as to the organisms evaluated and substrate used, being that the lower time of exposition prevents problems such as vandalism (Sheldon, 1977), or even the loss of sampling units due to increase in water flow. Shaw and Minshall (1980) found 64 days to be necessary to evaluate the colonization in pieces of basalt in an Idaho stream, while Roby et al. (1978) considered two to four weeks as the ideal period for the colonization of artificial substrate composed by porce- 
Table 3. Abundance (ind/experimental unit) and standard deviations of taxa more abundant in Marco and Silveira streams, being: AM3: opened unit removed in May with 36 days of colonization ( $n=4$ Marco and $n=3$ Silveira); FM3: unit of exclusion removed in May with 36 days of colonization ( $n=4$ Marco and $n=4$ Silveira); AJ3: opened unit removed in July with 36 days of colonization ( $n=4$ Marco and $n=3$ Silveira); FJ3: unit of exclusion removed in July with 36 days of colonization ( $n=4$ Marco and $n=4$ Silveira); A6: opened unit removed in July with 72 days of colonization ( $n=4$ Marco and $n=2$ Silveira) and F6: unit of exclusion removed in July with 72 days of colonization ( $n=4$ Marco and $n=2$ Silveira).

\begin{tabular}{lrrrrrr}
\hline & \multicolumn{5}{c}{ Marcos River } \\
\cline { 2 - 7 } & Ephemeroptera & \multicolumn{1}{c}{ Diptera } & \multicolumn{1}{c}{ Coleoptera } & Trichoptera & Lepidoptera & Plecoptera \\
\hline AM3 & $122.75(77.04)$ & $22.5(15.24)$ & $25.25(19.41)$ & $8.00(1.83)$ & $2.00(1.83)$ & $1.25(1.26)$ \\
FM3 & $223.25(87.28)$ & $53.50(34.35)$ & $16.50(5.69)$ & $7.75(3.83)$ & $1.75(0.96)$ & $1.25(0.50)$ \\
AJ3 & $230.50(58.21)$ & $24.50(4.12)$ & $9.00(6.22)$ & $3.50(1.73)$ & $2.75(0.96)$ & $1.00(1.15)$ \\
FJ3 & $362.50(69.41)$ & $72.00(20.77)$ & $18.00(8.48)$ & $4.50(1.73)$ & $3.50(3.32)$ & $4.25(2.36)$ \\
A6 & $351.50(248.81)$ & $54.25(49.41)$ & $19.25(8.30)$ & $14.75(15.56)$ & $6.75(3.30)$ & $2.25(3.20)$ \\
F6 & $339.50(212.42)$ & $48.25(33.66)$ & $17.5(6.66)$ & $15.25(9.53)$ & $5.50(3.11)$ & $14.25(15.76)$ \\
\hline \multicolumn{5}{c}{ Silveira River } \\
AM3 & Ephemeroptera & \multicolumn{1}{c}{ Diptera } & Coleoptera & Trichoptera & Gastropoda & Plecoptera \\
\hline FM3 & $269.67(118.75)$ & $213.67(189.69)$ & $12.67(2.89)$ & $28.33(22.19)$ & $63.67(46.00)$ & $4.67(7.23)$ \\
AJ3 & $188.75(41.60)$ & $249.25(243.14)$ & $17.75(11.95)$ & $33.00(26.95)$ & $97.75(50.88)$ & $6.25(8.62)$ \\
FJ3 & $88.00(25.51)$ & $208.67(78.05)$ & $20.00(8.89)$ & $6.33(1.53)$ & $49.33(19.14)$ & $3.33(2.08)$ \\
A6 & $144.50(50.32)$ & $626.50(429.24)$ & $10.50(8.66)$ & $30.75(14.93)$ & $84.50(54.75)$ & $19.50(7.23)$ \\
F6 & $98.00(59.40)$ & $44.50(28.99)$ & $5.00(5.66)$ & $4.00(2.83)$ & $71.50(19.09)$ & $1.00(0.00)$ \\
\hline & $196.50(180.31)$ & $219.50(215.67)$ & $13.50(10.61)$ & $72.50(4.95)$ & $41.50(58.69)$ & $44.50(7.78)$ \\
\hline
\end{tabular}

lain balls in a California stream. In the present work, despite the substrate used already having been colonized by epilithon, at 72 days, the abundance of Trichoptera and Plecoptera was higher in Marco stream, indicating that a longer colonization period might be necessary for the evaluation of predators on these organisms.

The possibility of predators determining the benthic macrofauna structure and abundance has been studied by some authors. Allan (1982) and Flecker and Allan (1984) did not find influence of predators on the invertebrates, but Bechara et al. (1993), Flecker and Townsend (1994), Dahl (1998) and Billy and Usseglio-Polatera (2002) found susceptibility of benthic invertebrates to fish predation. Hanson et al. (1990) observed a great impact of macroinvertebrate predators on the structure of the benthic community, the same being observed by Prejs and Prejs (1992). According to Sih and Wooster (1994), these differences are due to the way predators feed, in which the invertebrates cause significant local reductions to the amount of prey, while the vertebrates have a dubious effect, either reducing the prey density or not affecting it. The substrate, which provides shelter, is also considered by Bechara et al. (1993) as an important factor in the determination of predation of invertebrates by fishes. In the streams studied, when individually evaluated, Plecoptera showed differences in abundance when the exclusion was promoted in both streams. In Silveira stream, Trichoptera also presented higher abundance in the exclusion units of predators. Flecker and Allan (1984) and Prejs and Prejs (1992) pointed out that predation either by big inverte- brates or by fishes can affect some size classes of macroinvertebrates.

The species of predator fish can also be responsible for the different results, according to Cooper et al. (1990), salmonids normally present less or no effect on the prey as compared to cyprinids, for example, since salmonids feed mainly on organisms adrift, causing little effect on epibenthos. The autochtonous ichthyofauna of both streams presents differences in relation to its composition, though, A. brachypterygium has low occurrence in these streams (Winckler-Sosinski, 2004), having as the highest differential the possibility of not excluding J. eirmostigma.

According to Billy and Usseglio-Polatera (2002), the brown trout tends to feed on vulnerable invertebrates such as the ones that live in exposed microhabitats with a high tendency to drift. The same was found by Bechara et al. (1993) who observed that the impact of the trout is higher on epibenthos of a bigger size and drift insects due to the trout predation habit of selecting by size and appearance. In this work only the epibenthos were evaluated, and there were differences between the exclusion treatments in both streams. According to WincklerSosinski (2004), Trichoptera is considered one of the main foods of the rainbow trout, introduced in Silveira stream, in all the phases and places, which indicates that exotic fishes can change food habits in the new environment, and cause impacts that are not foreseen.

Among the changes caused by predators, Sih and Wooster (1994) point to the increase of some prey by the reduction of emigration rates. The change in prey 
behavior was also reported by Dahl (1998). Silveira stream presented lower amounts of Ephemeroptera and higher amounts of Gastropoda than Marco stream. Ephemeroptera are, according to Allan (1995), organisms more usually found in the drift.

Sih and Wooster (1994) also report that the reduction in competitors might lead to an increase in some organisms, when in the presence of predators. Besides the direct effect of the trout on the benthic community, its consumption of small fishes (Winckler-Sosinski, 2004) with insectivorous feeding habits such as the Bryconamerycus sp. (Bastos, 2002) may also lead to differences, which were observed between the streams.

Thus, it is possible to conclude that the exclusion treatment promotes an increase in the amount of Plecoptera in both streams, and of Trichoptera in Silveira stream, which shows that these organisms are influenced by predation. However, it is not possible to affirm that this difference is caused only by the presence of the trout once the other predators were also excluded. Disturbances such as differences in the use of the land also contribute to the difficulty in interpreting these data. However, one of the main items of trout diet is in the different composition in exclusion units. These differences indicate the changes to aquatic biota caused by introduction, as observed by McIntosh and Townsend (1996), since the exotic species may affect the behavior of some organisms and thus generate trophic effects in cascade. Therefore, studies must be performed on the local trophic chain, as well as studies on the macroinvertebrates adrift and their behavior when in the presence of the introduced species, in order to identify its effects on the community.

\section{References}

ALLAN, JD. 1982. The effects of redution in trout density on the invertebrate community of a mountain stream. Ecology, vol. 63 , no. 5 , p. $1444-1455$.

-, 1995. Drift. In ALLAN, JD (Ed.). Stream Ecology. London, UK: Chapman e Hall. 388 p.

BASTOS, JR., 2002. Biologia alimentar da taxocenose dos peixes do rio Silveira (cabeceira do rio Pelotas), São José dos Ausentes, Rio Grande do Sul, Brasil. Rio Grande do Sul: UFRGS. 67 p. [Dissertação de Mestrado].

BECHARA, JA, MOREAU, G. and HARE, L., 1993. The impact of brook trout (Salvelinus fontinalis) on an experimental stream benthic community: the role of spatial and size refugia. J. Anim. Ecol., vol. 62, no. 3, p. 451-464.

BILLY, VC. and USSEGLIO-POLATERA, P., 2002. Traits of brown trout prey in relation to habitat characteristics and benthic invertebrate communities. J. Fish. Biol., vol. 60, no. 3, p. 687-714.

COLLIER, KJ. and BOWMAN, EJ., 2003. Role of wood in pumice-bed streams I: impacts of post-harvest management on water quality, habitat and benthic invertebrates. Forest Ecol. Manag., vol. 177, no. 1-3, p. 243-259.
COLLIER, KJ. and SMITH, BJ., 2003. Corrigendum to "Role of wood in pumice-bed streams II: Breakdown and colonisation". Forest Ecol. Manag., vol. 181, no. 3, p. 375-390.

COOPER, SD., WALDE, S.J. and PECKARSKY, BL., 1990. Prey exchange rates and the impact of predators on prey populations in streams. Ecology, vol. 71, no. 4, p. 1503-1514.

DAHL, J. 1998. The impact of vertebrate and invertebrate predators on a stream benthic community. Oecologia, vol. 117, no. 1-2, p. 217-226.

DELARIVA, RL. and AGOSTINHO, AA., 1999. Introdução de espécies: uma síntese comentada. Acta Sci., vol. 21, no. 2, p. $255-262$

FERNÁNDEZ, HR. and DOMINGUEZ, ED., 2001. Guia para la determinación de los Artrópodos Bentónicos Sudamericanos. Serie Investigaciones de la UNT. Subserie Ciencias exactas e naturales. Tucumán, Argentina: Universidad Nacional de Tucumán ed. 282 p.

FLECKER, AS and ALLAN, D., 1984. The importance of predation, substrate and spatial refugia in determining lotic insect distributions. Oecologia, vol. 64, no. 3, p. 306-313.

FLECKER, AS. and TOWNSEND, CR., 1994. Community wide consequences of trout introduction in New Zealand streams. Ecol. Appl., vol. 4, no. 4, p. 798-807.

FLECKER, AS., 1992. Fish trophic guilds and the structure of a tropical stream: weak direct vs. strong indirect effects. Ecology, vol. 73 , no. 3, p. $927-940$.

GIDO, KB. and BROWN, JH., 1999. Invasion of north american drainages by alien fish species. Freshwater Biol., vol. 42, no. 2, p. 387-399.

HANSON, JM., CHAMBERS, PA. and PREPAS, EE., 1990. Seletive foraging by the crayfish Orconectes virilis and its impact on macroinvertebrates. Freshwater Biol., vol. 24, no. 1, p. 69-80.

HAUER, FR. and RESH, VH., 1996. Benthic macroinvertebrates. In HAUER, FR and LAMPERTI, G.A. (Eds.). Methods in stream ecology. London: Academic Press. 673 p.

KIKUCHI, RM. and UIEDA, VS., 1998. Composição da comunidade de invertebrados de um ambiente lótico e sua variação espacial e temporal. In NESSIMIAN, JL. and CARVALHO, AL. (Eds.). Ecologia de Insetos Aquáticos. (Série Oecologia brasiliensis V). Rio de Janeiro: PPG-UFRJ. p. $157-173$

LANCASTER, J., 1990. Predation and drift of lotic macroinvertebrates during colonization. Oecologia, vol. 85, no. 1, p. $48-56$.

LANCASTER, J. and ROBERTSON, AL., 1995. Microcrustacean prey and macroinvertebrate predators in a stream food web. Freshwater Biol., vol. 34, no. 1, p. 123-134.

MCCAFFERTY, WP., 1981. Aquatic Entomology - The Fishermen's and Ecologists. Illustrated Guide to Insects and their Relative. Boston: Jones and Bartlett Publishers, INC. $448 \mathrm{p}$.

MCINTOSH, AR. and TOWSEND, CR., 1996. Interactions between fish, grazing invertebrates and algae in a New Zealand stream: a trophic cascade mediated by fish-induced changes to grazer behaviour? Oecologia, vol. 108, no. 1, p. 174-181. 
MERRITT, RW. and CUMMINS, KW., 1996. Trophic relations of macroinvertebrates. In: HAUER, FR and LAMBERTI, GA. (Ed.). Methods in Stream Ecology. London: Academic Press. $673 \mathrm{p}$.

PILLAR, VDP. and ORLÓCI, L., 1996. On randomization testing in vegetation science: multifactor comparisons of relevé groups. J. Veg. Sci., vol. 7, no. 4, p. 585-592.

PILLAR, VDP., 2004a. MULTIV: Aplicativo para análise multivariada e testes de hipóteses. Porto Alegre: Depto. De Ecologia. UFRGS. Available from: <http//:ecologia.ecoqua. ufrgs.br>.

-, 2004b. SYNCSA: software for character-based community analysis. Porto Alegre: Depto. De Ecologia. UFRGS. Available from: $<$ http//:ecologia.ecoqua.ufrgs.br>.

PREJS, K. and PREJS, A., 1992. Importance of predation in regulating density of meio and macrofauna in seasonal tropical waters. Hydrobiologia, vol. 242, no. 2, p. 77-86.

RAHEL, FJ. and STEIN, RA., 1988. Complex predatorprey interactions and predator intimidation among crayfish, piscivorous fish, and small benthic fish. Oecologia, vol. 75, no. 1, p. 94-98.

ROBY, KB., NEWBOLD, JD. and ERMAN, CD., 1978. Effectiveness of an artificial substrate for sampling macroinvertebrates in small streams. Freshwater Biol., vol. 8, no. 1, p. $1-8$.

SHAW, DW. and MINSHALL, GW., 1980. Colonization of an introduced substrate by stream macroinvertebrates. Oikos, vol. 34 , no. 3 , p. $259-271$.
SHELDON, AL., 1977. Colonization curves: application to stream insects on semi-natural substrates. Oikos, vol. 28, no. $2-3$, p. $256-261$.

SIH, A. and WOOSTER, DE., 1994. Prey behavior, prey dispersal, and predator impacts on stream prey. Ecology, vol. 75, no. 5 , p. $1199-1207$.

SOLUK, DA. and COLLINS, NC., 1988. Synergistic interactions between fish and stoneflies: facilitation and interference among streams predators. Oikos, vol. 52, no. 1, p. 94-100.

STRIXINO G. and STRIXINO, ST., 1982. Insetos aquáticos guia de identificação. São Carlos: Depto de Ciências Biológicas, UFSCar. 69 p.

THORP, JH. and BERGEY, EA., 1981. Field experiments on responses of a freshwater, benthic macroinvertebrate community to vertebrate predators. Ecology, vol. 62, no. 2, p. 365-375.

VANNOTE, RL., MINSHALL, GW., CUMMINS, KW., SEDELL, JR. and CUSHING, CE., 1980. The river continuum concept. Can. J. Fish. Aquat. Sci., vol. 37, p. 130-137.

WILZBACH, MA., CUMMINS, KW. and HALL, JD., 1986. Influence of habitat manipulations on interactions between cutthroat trout and invertebrate drift. Ecology, vol. 67, no. 4, p. 898-911.

WINCKLER-SOSINSKI, LT. 2004. Introdução da truta arcoíris (Oncorhynchus mykiss) e suas conseqüências para a comunidade aquática dos rios de altitude do sul do Brasil. Rio Grande do Sul: UFRGS. 245 p. [Tese de Doutorado]. 